\title{
TITLE:
}

\section{Cyclic Model for the Asymmetric Conjugate Addition of Organolithiums with Enoates}

\section{$\operatorname{AUTHOR}(\mathrm{S})$ :}

Nishimura, Katsumi; Fukuyama, Naoshi;

Yamashita, Mitsuaki; Sumiyoshi, Takaaki;

Yamamoto, Yasutomo; Yamada, Ken-ichi; Tomioka, Kiyoshi

\section{CITATION:}

Nishimura, Katsumi ... [et al]. Cyclic Model for the Asymmetric Conjugate Addition of Organolithiums with Enoates. Synthesis 2015, 47(15): 22562264

\section{ISSUE DATE:}

2015-07-21

URL:

http://hdl.handle.net/2433/202033

\section{RIGHT:}

(c) Georg Thieme Verlag Stuttgart · New York; The full-text file will be made open to the public on 21 July 2016 in accordance with publisher's 'Terms and Conditions for Self-Archiving'; この論文は著者最終稿です。内容が印刷版と異 なることがありますので、引用の際には出版社版をご確認ご利用ください。This is the Accepted Author Manuscript. Please cite only the published version. 


\title{
Cyclic Model for the Asymmetric Conjugate Addition of Organolithium with Enoate
}

\author{
Katsumi Nishimura, ${ }^{a}$ Naoshi Fukuyama, ${ }^{a}$ Mitsuaki Yamashita, ${ }^{a}$ Takaaki Sumiyoshi, ${ }^{a}$ Yasutomo Yamamoto, ${ }^{b}$ Ken-ichi \\ Yamada, ${ }^{a}$ Kiyoshi Tomioka, ${ }^{\mathrm{a}, \mathrm{b}}$. \\ ${ }^{a}$ Graduate School of Pharmaceutical Sciences, Kyoto University, Yoshida, Sakyo-ku, Kyoto 606-8501, Japan \\ ${ }^{\mathrm{b}}$ Faculty of Pharmaceutical Sciences, Doshisha Women's College of Liberal Arts, Kodo, Kyotanabe 610-0395, Japan \\ Fax: +81-774-65-8658 \\ E-mail:ktomioka@dwc.doshisha.ac.jp
}

Received: The date will be inserted once the manuscript is accepted.

\begin{abstract}
The chiral diether ligand-controlled asymmetric conjugate addition of organolithiums to nona-2,7-dienedioate preferentially proceeded via the s-cis conformation with coordination of the carbonyl oxygen atom to the lithium to give $E$ lithium enolate intermediate. Subsequent intramolecular conjugate addition of the enolate also proceeded via the cyclic transition state involving the lithium and the s-cis-enoate, and trans,trans-trisubstituted cyclohexanes were obtained with high ee and yields.
\end{abstract}

Key words: chiral ligand, asymmetric synthesis, organolithiums, conjugate addition, cascade reaction

Asymmetric conjugate addition of carbonucleophile to electron-deficient olefin is one of the most attractive and powerful methods for an asymmetric construction of carbon-carbon bonds. ${ }^{1}$ It is advantageous that an initial product of asymmetric conjugate addition of an organolithium to an $\alpha, \beta$-unsaturated carbonyl compound is a chiral lithium enolate and thus can further react with an electrophile to form an additional bond. The conformation of the $\alpha, \beta$-unsaturated carbonyl compound, i.e., s-cis or s-trans, is responsible to the facial selectivity of the conjugate addition and also to the E,Z-geometry of the resulting enolate, which should then governs the diastereoselectivity of the subsequent reaction with other electrophiles. Accordingly, the reactive conformation of carbonyl compounds in which conjugate addition occurs has been a central matter of interest. ${ }^{2}$

We have been engaged in an external chiral ligand controlled asymmetric conjugate addition reaction of a variety of lithiated nucleophiles such as organolithium, lithium ester enolate, lithium thiolate, and lithium amide to linear $\alpha, \beta$-unsaturated imine, ${ }^{3}$ enoate ${ }^{4,5,6}$ and nitroolefin ${ }^{7}$. Our NMR studies revealed that chiral diether ligand 1 and a lithium reagent form $C_{2^{-}}$ symmetric-like ${ }^{8}$ five-membered chelate complex 2 by coordination of the two ethereal oxygen atoms of 1 to the lithium atom, in which the methyl groups on the oxygen atoms are fixed to situate up and down faces of chelation $\mathbf{2}$ avoiding steric repulsion by the phenyl groups on the chiral centers. ${ }^{9}$ The reaction of complex $\mathbf{2}$ with enoate $\mathbf{3}$ afforded conjugate addition product $\mathbf{5}$ with high enantioselectivity. On the basis of the relationship between the newly created stereogenic center in $\mathbf{5}$ and chiral chelate complex $\mathbf{2}$, we proposed cyclic reaction model $\mathbf{X}$, in which the lithium atom is coordinated by the carbonyl oxygen atom of s-cis-enoate on the olefin side. The olefin moiety is placed in the less crowded space avoiding the steric repulsion by the two methyl groups of 2 (Scheme 1). ${ }^{3 a, 3 b, 5 b, 10}$ Then, $\mathrm{R}$ group attacks the olefin moiety from underneath to give, after protonation of the resulting $E$-enolate 4, 5 with the observed absolute configuration. ${ }^{3-7}$ If $s$-transenoate, instead of $s$-cis, were involved in the reaction, $Z$-enolate with the opposite absolute configuration would result.

Although the similar cyclic reaction models were proposed by some other groups for the conjugate addition of lithium amide to s-cis-enoate, ${ }^{2 \mathrm{a}, \mathrm{j}, \mathrm{k}}$ lithiuminvolved models with s-trans-enoate were also proposed for the conjugate addition of lithium enolate ${ }^{11}$ and methyllithium. ${ }^{12}$ Thus, determination of the reactive conformation of an $\alpha, \beta$-unsaturated carbonyl compound in the conjugate addition of lithium reagent is still a formidable challenging target. Instead of direct identification of enolate geometry, conjugate addition and following Michael cyclization of the resulting enolate with intramolecular enoate were designed to identify the enolate geometry as shown in Scheme 2.
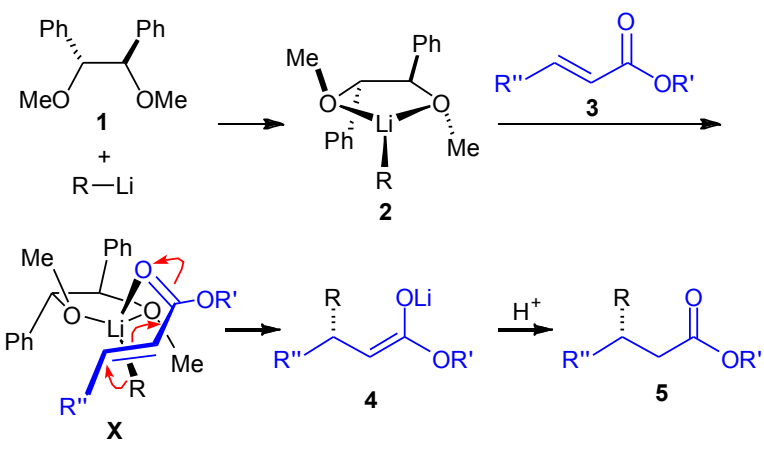

Scheme 1 Our proposal for chiral diether ligand 1-mediated asymmetric conjugate addition of lithium reagents to $\alpha, \beta$ unsaturated carbonyl compounds.

The asymmetric conjugate addition of organolithi$\mathrm{um}^{13,14}$ to $C_{2}$ symmetric nona-2,7-dienedioate $\mathbf{6}$ is a cascade reaction ${ }^{15}$ to provide chiral cyclohexanes 2 bearing three contiguous chiral centers, stereochemistry of which provides us an insight into reactive conformation of alkenoates that undergo the conjugate addition (Scheme 2). The addition of organolithium to s-cis-6 preferentially gives $E$-enolate via the cyclic 
transition state, while that to s-trans-6 leads to the $Z$ enolate. When the resulting $E$ - and $Z$-enolates undergo subsequent conjugate addition to the internal alkenoate moiety with s-cis conformation, trans, trans-tt-7 (scis-s-cis product) and trans,cis-tc-7 (s-trans-s-cis product) should be obtained, respectively, and $c t-7$ and cc-7 would be quite minor products. The addition reaction of $E$ - and $Z$-enolate through s-trans conformation would give $\boldsymbol{t c}-\mathbf{7}$ (s-cis-s-trans product) and $\boldsymbol{t} \boldsymbol{t}-\mathbf{7}$ (s-trans-s-trans product) as major products, respectively. Herein, we report details of the stereochemistry of the asymmetric conjugate addition cascade preferentially giving $\boldsymbol{t t}-\mathbf{7}$ as well as the preferred cyclic $s$-cis conformation of the alkenoates moieties.

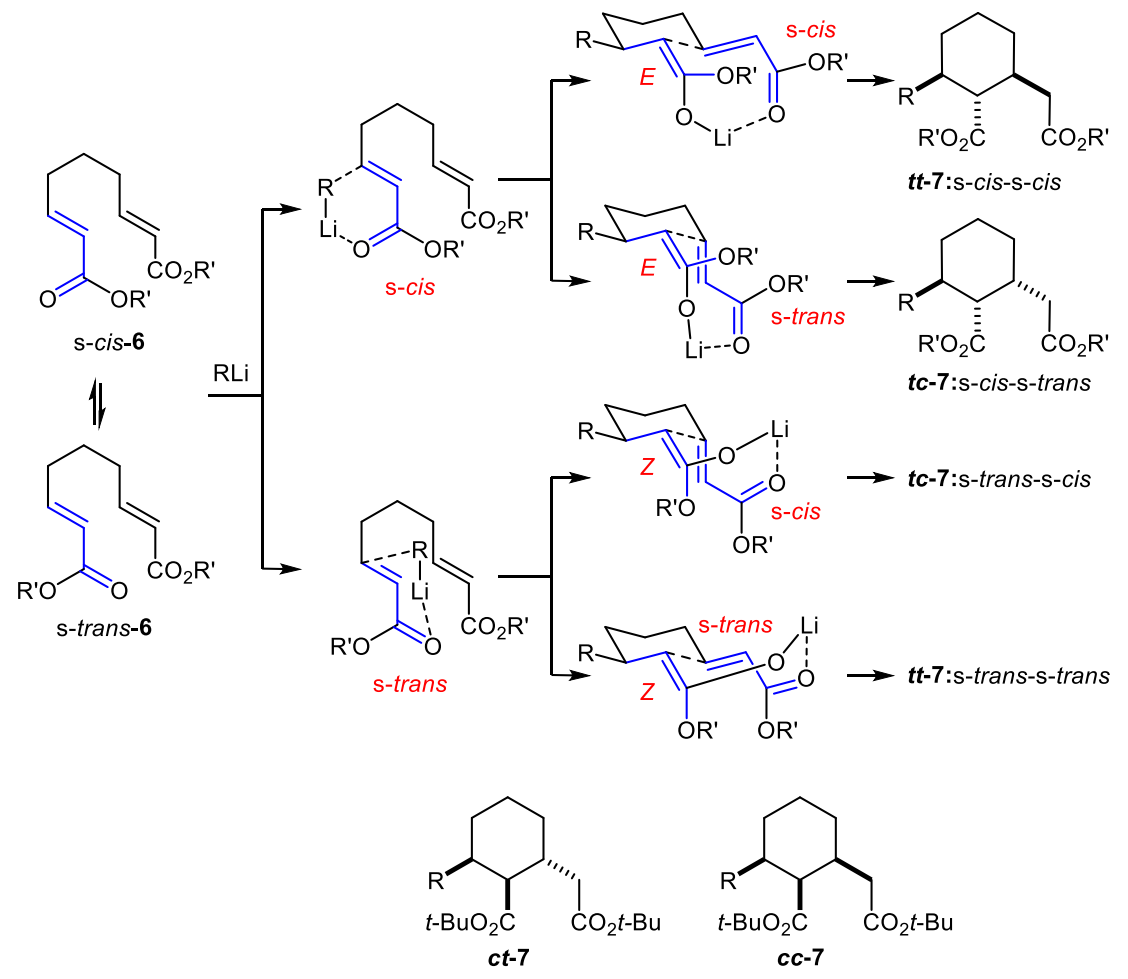

Scheme 2. Products of conjugate addition-Michael cyclization cascade.

At the outset of our studies, the cascade reaction of phenyllithium with bis-BHA (2,6-di-tert-butyl-4methoxyphenyl) enoate $\mathbf{6 a}$ was attempted in the presence of 1 (eq 1). ${ }^{4 \mathrm{a}}$ To a toluene solution of 1 ( 2 equiv) at $-78{ }^{\circ} \mathrm{C}$, were added solutions of phenyllithium (1.5 equiv) in cyclohexane-diethyl ether and then $6 \mathbf{a}$ in toluene $20 \mathrm{~min}$ apart. After $20 \mathrm{~min}$ reaction, simple conjugate addition product 9a with $87 \%$ ee was obtained in $56 \%$ yield along with recovered $6 \mathbf{a}$ in $13 \%$ yield without production of desired cascade products 7. Even when the reaction mixture was gradually warmed up from $-78{ }^{\circ} \mathrm{C}$, no cyclization took place below $-20^{\circ} \mathrm{C}$, while production of 2,6-di-tert-butyl-4methoxyphenol was observed, probably due to elimination from the intermediate lithium enolate at the elevated temperature.
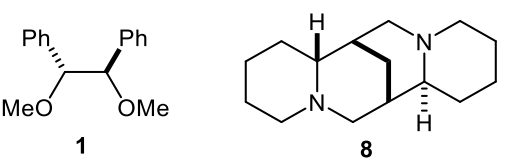

Figure 1 Chiral ligands for organolithium compounds.

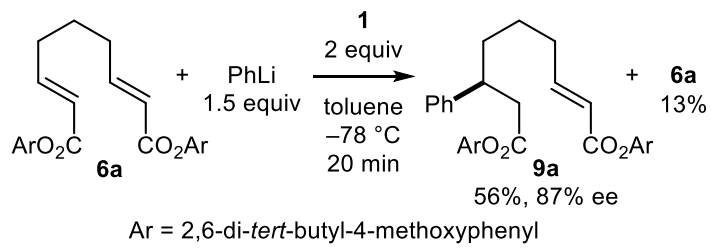

Equation 1

Then, di-tert-butyl ester $\mathbf{6 b}$ of decrease steric hindrance was selected as a bis(enoate). To our delight, the reaction of $\mathbf{6 b}$ and phenyllithium (3 equiv) complexed with 1 (4.2 equiv) was completed within $0.5 \mathrm{~h}$ to give desired cascade products trans,transcyclohexane $\boldsymbol{t} \boldsymbol{t}-\mathbf{7 a}$ with $71 \%$ ee in $50 \%$ yield and trans,cis-cyclohexane $t$ c-7a with $3 \%$ ee in $9 \%$ yield (Table 1 , entry 1 ). The relative and absolute configuration of $\boldsymbol{t t}$-7a was unambiguously determined by derivatization. ${ }^{15 \mathrm{~b}}$ The other diastereomers $c t-7$ and $c c$ 7 were not obtained. It is noteworthy that $\mathbf{6 b}$ mainly reacted with only one equivalent of phenyllithium. Even though $\mathbf{6 b}$ was added into the solution of the excess amount of phenyllithium and 1, only slight amount of double phenylated product 10a (see eq 2) was produced $(<10 \%)$. In contrast, when the reaction was conducted in THF as a solvent without 1, 10a was 
mainly produced ( $79 \%$ yield; eq 2 ), and only tiny amount of $\boldsymbol{t} \boldsymbol{t}-\mathbf{7 a}$ and $\boldsymbol{t c}-\mathbf{7 a}$ were obtained (9\% and $4 \%$ yields, respectively). ${ }^{16}$ These results clearly indicate that chiral ligand 1 significantly accelerates the intramolecular conjugate addition of the enolate to the intramolecular enoate.

Table 1 Asymmetric conjugate addition cascade.

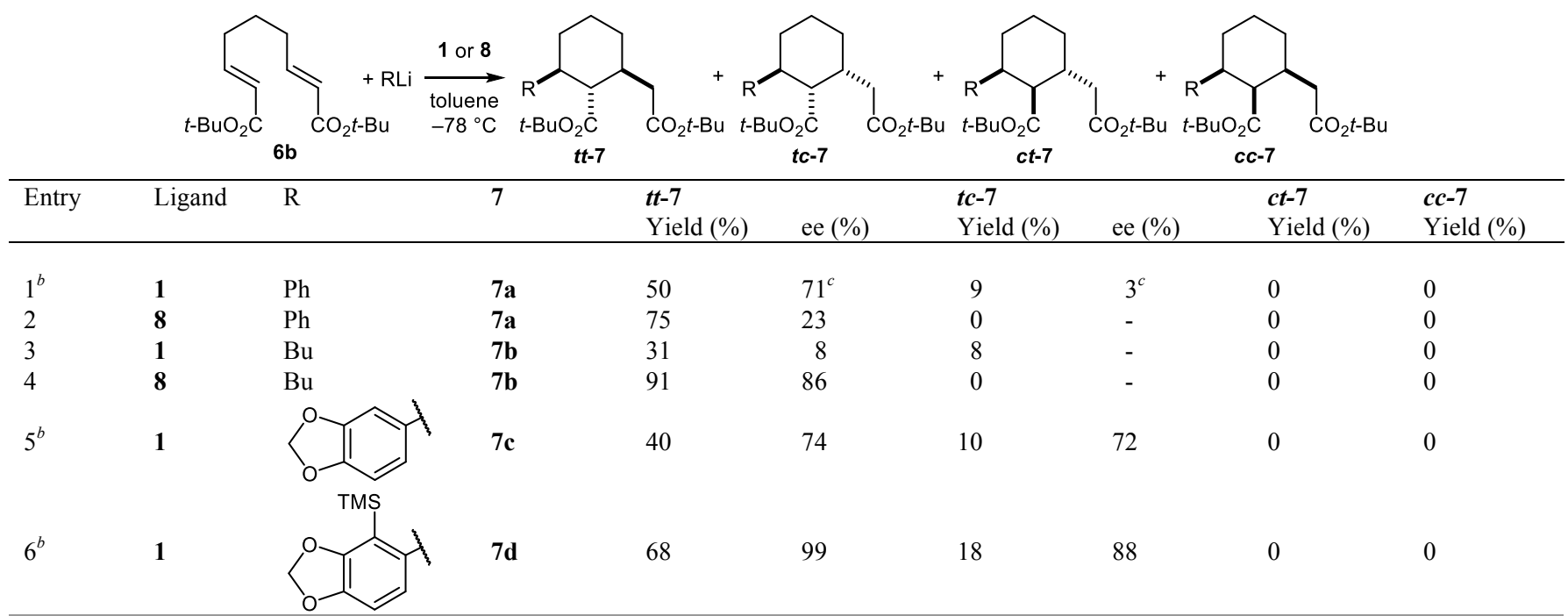

${ }^{a}$ All reactions were carried out using RLi ( 3 equiv) and 1 or 8 (4.2 equiv). ${ }^{b}$ Data from ref $15 \mathrm{~b} .{ }^{c}$ The ee was determined after derivatization (see ref. 15b).

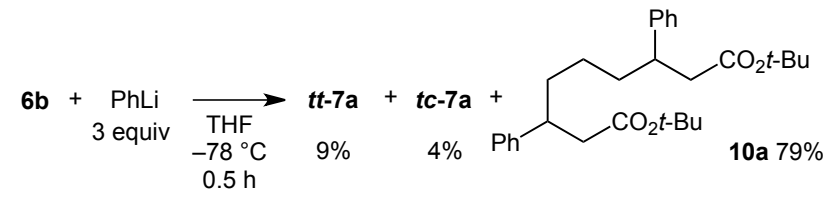

Equation 2

The asymmetric cascade cyclization reactions of aryland alkyllithiums were possible by using our chiral diether ligand $\mathbf{1}$ and (-)-sparteine (8) (Figure 1). ${ }^{4 a}$ Chiral diether 1 and (-)-sparteine (8) were complementary chiral ligands controlling the reactions of aryllithium and $s p^{3}$ organolithium butyllithium, respectively. The reaction of butyllithium was controlled by 8 to give $\boldsymbol{t t}$-7b with $86 \%$ ee in $91 \%$ yield as a single diastereomer (entry 4), while the use of $\mathbf{1}$ as a chiral ligand produced $\boldsymbol{t} t \mathbf{- 7 b}$ with miserable ee $(8 \%)$ in $31 \%$ yield (entry 3 ). In the reaction of phenyllithium, $\mathbf{8}$ was a less effective chiral ligand than $\mathbf{1}$ to give $\boldsymbol{t t}-\mathbf{7 a}$ with low $23 \%$ ee (entry 2). Interestingly, the diastereoselection was perfectly controlled in the reactions using $\mathbf{8}$, and neither $\boldsymbol{t c} \mathbf{- 7} \mathbf{a}$ nor $\boldsymbol{t} \boldsymbol{c} \mathbf{- 7} \mathbf{7}$ was produced in entries 2 and 4.

For the reaction of an aryllithium, installation of a removable bulky substituent, such as a TMS group, at the ortho-position was effective to enhance the enantioselectivity (entries 5 and 6). ${ }^{15 b}$ It is noteworthy that the product cyclohexanes 7 bearing three contiguous stereogenic centers were useful for the asymmetric total synthesis of Amaryllidaceae alkaloids (-)lycorine $^{15 \mathrm{a}}$ and $(+)-\beta$-lycorane. ${ }^{15 \mathrm{~b}}$

In all these reactions in Table 1 , only slight amount $(<10 \%$ in total) of 1,2-addition products and 3,7-diaryl products 10 were produced. Importantly, chiral ligand
1 was quantitatively recovered without any loss of optical purity, and was reusable.

Based on the consideration made in Scheme 1, the formation of $\boldsymbol{t t}$-7, having trans,trans-configuration, as the major product suggests two possibilities: (1) the first conjugate addition proceeded with s-cis-6 to give $E$-enolate as an intermediate, which underwent the intramolecular conjugate addition with the alkenoate moiety in s-cis conformation, or (2) the first conjugate addition proceeded with s-trans-6, and the resulting $Z$ enolate undergoes the conjugate addition in s-trans conformation. Our studies then went to solve this problem.

Monophenyl adduct di-tert-butyl ester 9b and dimethyl ester 9c were prepared from $(E)$-tert-butyl 7hydroxyhept-2-enoate $\mathbf{1 1}^{17}$ (Scheme 3). Hydroxy group of $\mathbf{1 1}$ was protected by THP, and then conjugate addition of $\mathrm{PhLi}$ followed by deprotection of THP

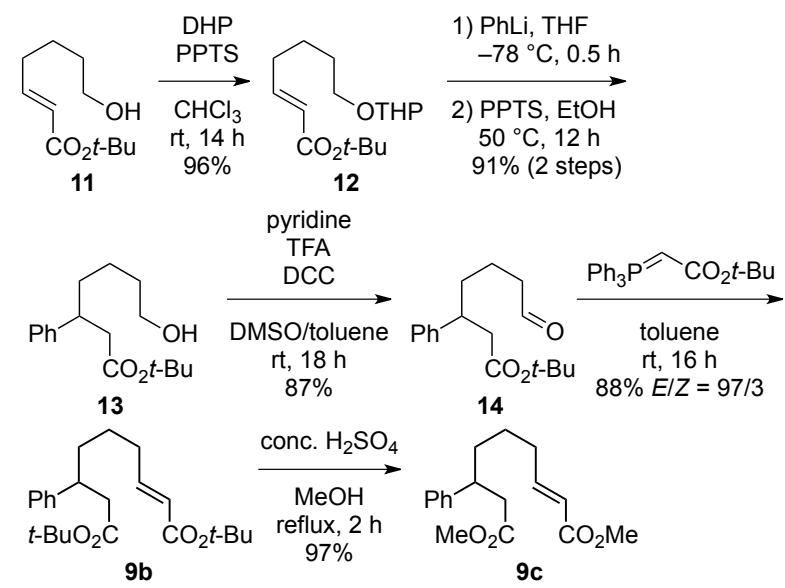

Scheme 3 Preparation of monophenyl adducts $9 \mathbf{b}$ and $9 c$. 
group afforded 13. Pfitzner-Moffatt oxidation of $\mathbf{1 3}$ and the following Wittig reaction gave 9b. Dimethyl ester 9c was prepared by in situ methyl esterification of $9 \mathrm{~b}$ under Fischer conditions.

Lithium enolate formation and then intramolecular Michael reaction of $9 b$ and $9 c$ was examined by treating with LDA (1.2 equiv) in THF at $-78{ }^{\circ} \mathrm{C}$ (Scheme 4). The reaction of $9 \mathbf{b}$ mainly produced $t \boldsymbol{t}-\mathbf{7 a}$, which is also the main product of the cascade reaction of $6 \mathbf{b}$, in $66 \%$ yield along with $t c-7 \mathbf{a}$ in $28 \%$ yield. In contrast, diastereoselectivity was opposite for $\mathbf{9 c}$, and $\boldsymbol{t c} \mathbf{c - 7 e}$ was obtained as a major product in $75 \%$ yield along with $\boldsymbol{t} \boldsymbol{t}$-7e as a minor product in $17 \%$ yield. The observed difference in diastereoselectivity certainly reflected the difference in the geometry of the lithium enolates that formed from 9b and 9c. Interestingly, the reaction of dimethyl dienedioate $\mathbf{6 c}\left(\mathrm{R}^{\prime}=\mathrm{Me}\right)$ with phenyllithium in THF at $-78{ }^{\circ} \mathrm{C}$ gave trans, trans-product $\boldsymbol{t t}$-7e in $19 \%$ yield as a major product and $t c-7 e$ in $3 \%$ yield, showing the same stereochemical tendency as that of di-tert-butyl bis(enoate) $\mathbf{6 b}$. These results clearly indicate that the geometry of the lithium enolate that formed by the deprotonation of $9 \mathbf{b}$ should be the same as that formed by the conjugate addition of $\mathbf{6 b}$, whereas those should be different between dimethyl esters 9c and $\mathbf{6 c}$.

The deprotonation of methyl ester 9c probably proceeded via 6-membered transition state $\mathbf{C}$ according to the Ireland model, ${ }^{18}$ where the 1,3-diaxial interaction between the $\alpha$-substituent of the ester and the isopropyl group of LDA was avoided, to give enolates with $Z$-geometry. Hence, $\boldsymbol{t c - 7 e}$ was obtained as a major product via the conjugate addition through s-cis transition state D. Indeed, deprotonation of 9c with LDA in $23 \%$ HMPA-THF, ${ }^{18}$ under which an $E$ enolate should formed via an open transition state, led to the opposite diastereoselectivity, giving $\boldsymbol{t t}-\mathbf{7 e}$ as a major product in $21 \%$ yield along with $t c-7 e$ in $9 \%$ yield. The low yields were due to competitive $\gamma$ deprotonation of the alkenoate moiety giving rise to the corresponding deconjugated $Z$ - and $E$-alkenoates in $28 \%$ and $6 \%$ yield, respectively.

Deprotonation of ketones by LDA preferentially gives $E$-enolate via analogous transition states to $\mathbf{A}$ to avoid steric repulsion between the two substituents on the carbonyl carbons. ${ }^{18}$ Therefore, it is highly probable that the deprotonation of tert-butyl ester 9b mainly proceeded via transition state A due to the bulkiness of the $\alpha$-substituent and the tert-butoxy moiety, giving $E$-enolate. As a consequence, $\boldsymbol{t} \boldsymbol{t}-\mathbf{7 a}$ was produced as a major product by subsequent intramolecular conjugate addition via s-cis transition state B. All these results lead to the conclusion that the lithium enolate intermediate should undergo the intramolecular conjugate addition in s-cis conformation, and consequently, that the both conjugate addition should proceed with the alkenoate moieties in s-cis conformation as proposed in the above possibility (1).

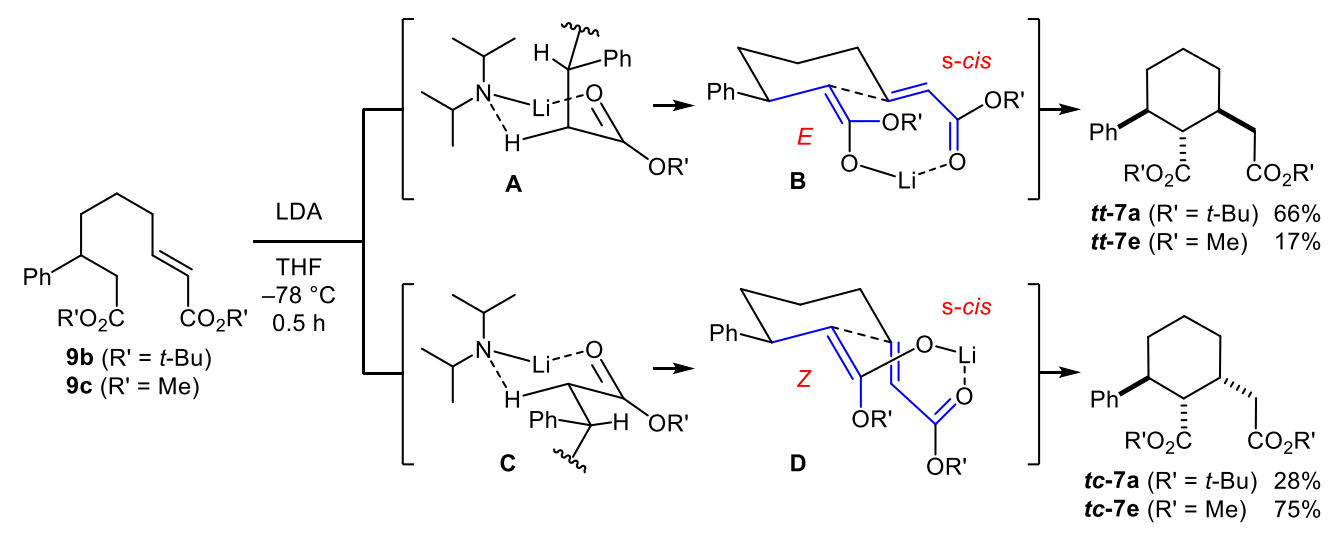

Scheme 4 Cyclization of Monophenyl Adducts $\mathbf{5 b}$ and $\mathbf{5 c}$ with LDA.

In summary, we have developed the chiral ligandsmediated asymmetric conjugate addition cascade of nonadienedioate with organolithiums to give cyclohexanes bearing three contiguous stereogenic centers with trans,trans-configuration in high optical purity. Based on the stereochemical consideration, the preferred alkenoate conformation in the conjugate addition was confirmed to be s-cis giving $E$-enolate. This methodology enables the formation of two $\mathrm{C}-\mathrm{C}$ bonds and three stereogenic centers in one pot to give synthetically useful chiral cyclohexane derivatives.
All melting points are uncorrected. Silica gel was used for column chromatography. ${ }^{1} \mathrm{H}$ and ${ }^{13} \mathrm{C}$ NMR (500 and $125 \mathrm{MHz}$, respectively) were measured in $\mathrm{CDCl}_{3}$ unless otherwise mentioned. Chemical shifts and coupling constants are presented in ppm $\delta$ relative to tetramethylsilane and $\mathrm{Hz}$, respectively. The wavenumbers of maximum absorption peaks of IR spectroscopy are presented in $\mathrm{cm}^{-1}$. Chiral ligand $\mathbf{1}$ was prepared as previously described, ${ }^{19}$ while $\mathbf{8}$ is commercially available. Preparation and physical and spectroscopic data of $\mathbf{6 b}, 7 \mathbf{a}, 7 \mathbf{c}$ and $7 \mathbf{d}$ were previously reported. ${ }^{15 \mathrm{~b}}$

\section{(E,E)-Bis-(2,6-di-tert-butyl-4-methoxyphenyl) nona-2,7-dienedioate (6a)}


To a stirred solution of triphenylphosphine $(525 \mathrm{~g}, 2.0$ $\mathrm{mol})$ in toluene $(1.0 \mathrm{~L})$ was added ethyl bromoacetate $(0.22 \mathrm{~L}, 2.0 \mathrm{~mol})$ dropwise over $1 \mathrm{~h}$ at rt. After $5 \mathrm{~h}$, the mixture was filtered. The residue was washed with toluene $(1.0 \mathrm{~L})$ and hexane $(0.80 \mathrm{~L})$, and then suspended in $\mathrm{H}_{2} \mathrm{O}(4.0 \mathrm{~L})$. To the suspension cooled in an ice-water bath, was added aqueous $10 \% \mathrm{NaOH}(0.80$ L) dropwise over $1 \mathrm{~h}$. The suspension was filtered, and the residue was washed with $\mathrm{H}_{2} \mathrm{O}(0.25 \mathrm{~L} \times 3)$ to give ylide (643 $\mathrm{g}, 92 \%)$ as a white solid of $\mathrm{mp} 120$ $122{ }^{\circ} \mathrm{C}$. To a stirred suspension of the ylide $(572 \mathrm{~g}$, $1.64 \mathrm{~mol})$ in toluene $(1.2 \mathrm{~L})$ was dropwise added a solution of glutaraldehyde ( $65 \mathrm{~g}, 0.65 \mathrm{~mol})$ in toluene $(0.10 \mathrm{~L})$ at rt. After $18 \mathrm{~h}$, the mixture was filtered, and the residue was washed with hexane $(0.50 \mathrm{~L})$. The combined filtrate and washings were concentrated in vacuo to give unsaturated ester as an yellow oil (255 g). To a stirred solution of the ester in EtOH $(0.32 \mathrm{~L})$ was added a solution of $\mathrm{NaOH}(130 \mathrm{~g}, 3.3 \mathrm{~mol})$ in $\mathrm{H}_{2} \mathrm{O}(0.32 \mathrm{~L})$ at rt. After $2 \mathrm{~h}$, the mixture was concentrated in vacuo, and $\mathrm{H}_{2} \mathrm{O}(0.40 \mathrm{~L})$ was added. The mixture was filtered, and the filtrate was acidified with aqueous $10 \% \mathrm{HCl}(0.70 \mathrm{~L})$ to give dicarboxylic $\operatorname{acid}^{20}$ as a white solid. The resulting white solid (47 g) was collected by filtration. To a solution of the carboxylic acid (200 $\mathrm{mg}, 1.09 \mathrm{mmol})$ and 2,6-di-tertbutyl-4-methoxyphenol $(513 \mathrm{mg}, 2.17 \mathrm{mmol})$ in toluene $(3 \mathrm{~mL})$ was added TFAA $(0.92 \mathrm{~mL}, 6.5 \mathrm{mmol})$ at rt. After stirred for 6 days at $40{ }^{\circ} \mathrm{C}$, the mixture was cooled in an ice-water bath, and aqueous $10 \% \mathrm{NaOH}$ $(6 \mathrm{~mL})$ was dropwise added over $5 \mathrm{~min}$. After stirred for $30 \mathrm{~min}$ at $\mathrm{rt}$, the mixture was extracted with AcOEt $(30 \mathrm{~mL} \times 3)$. The combined organic layers were washed with $10 \% \mathrm{NaOH}(40 \mathrm{~mL}), 10 \% \mathrm{HCl}(40 \mathrm{~mL})$, saturated $\mathrm{NaHCO}_{3}(40 \mathrm{~mL})$, and brine $(40 \mathrm{~mL})$, dried over $\mathrm{Na}_{2} \mathrm{SO}_{4}$, and concentrated in vacuo to give brown oil $(685 \mathrm{mg})$, which was purified by column chromatography (hexane/AcOEt $=20 / 1$ ) to give the title compound $(340 \mathrm{mg}, 50 \%)$ as a white solid of $\mathrm{mp}$ 171.5-172.0 ${ }^{\circ} \mathrm{C}(\mathrm{MeOH})$ along with the following products: $R_{f}=0.2$ (hexane/Et $\left.{ }_{2} \mathrm{O}=6 / 1\right) .{ }^{1} \mathrm{H}$ NMR: 1.33 (s, 36H), 1.80 (quintet, $J=7.3,2 \mathrm{H}), 2.39(\mathrm{~m}, 4 \mathrm{H})$, $3.80(\mathrm{~s}, 6 \mathrm{H}), 6.13(\mathrm{~d}, J=15.6,2 \mathrm{H}), 6.87(\mathrm{~s}, 4 \mathrm{H}), 7.16$ $(\mathrm{dt}, J=15.6,6.7,2 \mathrm{H}) .{ }^{13} \mathrm{C}$ NMR: $26.1\left(\mathrm{CH}_{2}\right), 31.4$ $\left(\mathrm{CH}_{3}\right), 31.6\left(\mathrm{CH}_{2}\right), 35.6(\mathrm{C}), 55.2\left(\mathrm{CH}_{3}\right), 111.6(\mathrm{CH})$, $122.7(\mathrm{CH}), 141.4(\mathrm{C}), 143.5(\mathrm{C}), 150.3(\mathrm{CH}), 156.2$ (C), $166.8(\mathrm{C})$. IR $\left(\mathrm{CDCl}_{3}\right): 1730,1650,1590$. EIMS $m / z: 621(\mathrm{M}+\mathrm{H}), 385,329,236$. Anal. calcd for $\mathrm{C}_{39} \mathrm{H}_{56} \mathrm{O}_{6}:$ C, 75.45; H, 9.09. Found: C, 75.18; H, 9.04.

\section{(E,Z)-Bis-(2,6-di-tert-butyl-4-methoxyphenyl) nona-2,7-dienedioate}

A yellow oil $(89 \mathrm{mg}, 13 \%): R_{f}=0.3$ (hexane/ $\mathrm{Et}_{2} \mathrm{O}=$ 6/1). ${ }^{1} \mathrm{H}$ NMR: 1.30 (s, 18H), 1.33 (s, 18H), 1.70 (quintet, $J=7.6,2 \mathrm{H}), 2.33(\mathrm{~m}, 2 \mathrm{H}), 2.78(\mathrm{~m}, 2 \mathrm{H})$, $3.791(\mathrm{~s}, 3 \mathrm{H}), 3.794(\mathrm{~s}, 3 \mathrm{H}), 6.07(\mathrm{~d}, J=15.6,1 \mathrm{H})$, $6.14(\mathrm{~d}, J=11.3,1 \mathrm{H}), 6.47(\mathrm{dt}, J=11.3,7.6,1 \mathrm{H})$, $6.85(\mathrm{~s}, 2 \mathrm{H}), 6.87(\mathrm{~s}, 2 \mathrm{H}), 7.14(\mathrm{dt}, J=15.6,6.7,1 \mathrm{H})$. ${ }^{13} \mathrm{C}$ NMR: $27.2\left(\mathrm{CH}_{2}\right), 28.6\left(\mathrm{CH}_{2}\right), 31.3\left(\mathrm{CH}_{3}\right), 31.4$ $\left(\mathrm{CH}_{3}\right), 32.1\left(\mathrm{CH}_{2}\right), 35.5(\mathrm{C}), 35.6(\mathrm{C}), 55.17\left(\mathrm{CH}_{3}\right)$, $55.22\left(\mathrm{CH}_{3}\right), 111.5(\mathrm{CH}), 111.6(\mathrm{CH}), 120.8(\mathrm{CH})$,
$122.2(\mathrm{CH}), 141.2(\mathrm{C}), 141.5(\mathrm{C}), 143.5(\mathrm{C}), 143.6(\mathrm{C})$, $150.9(\mathrm{CH}), 151.8(\mathrm{CH}), 156.18(\mathrm{C}), 156.22(\mathrm{C})$, 166.6 (C), 166.9 (C). IR (neat): 1740, 1640, 1590. EIMS $m / z: 621(\mathrm{M}+\mathrm{H}), 385,329,236$. Anal. calcd for $\mathrm{C}_{39} \mathrm{H}_{56} \mathrm{O}_{6}$ : C, 75.45; H, 9.09. Found: C, 75.42; H, 9.33 .

\section{(Z,Z)-Bis-(2,6-di-tert-butyl-4-methoxyphenyl) nona-2,7-dienedioate}

A yellow oil $(4 \mathrm{mg}, 1 \%): R_{f}=0.4\left(\right.$ hexane $\left./ \mathrm{Et}_{2} \mathrm{O}=6 / 1\right)$. ${ }^{1} \mathrm{H}$ NMR: $1.24(\mathrm{~s}, 36 \mathrm{H}), 1.55(\mathrm{~m}, 2 \mathrm{H}), 2.66(\mathrm{~m}, 4 \mathrm{H})$, $3.72(\mathrm{~s}, 6 \mathrm{H}), 6.00(\mathrm{~d}, J=11.3,2 \mathrm{H}), 6.38(\mathrm{dt}, J=11.3$, 7.7, 2H), $6.78(\mathrm{~s}, 4 \mathrm{H}) .{ }^{13} \mathrm{C}$ NMR: $27.9\left(\mathrm{CH}_{2}\right),-28.4$ $\left(\mathrm{CH}_{2}\right), 31.4\left(\mathrm{CH}_{3}\right), 35.6(\mathrm{C}), 55.2\left(\mathrm{CH}_{3}\right), 111.6(\mathrm{CH})$, $120.4(\mathrm{CH}), 141.3(\mathrm{C}), 143.5(\mathrm{C}), 152.3(\mathrm{CH}), 156.2$ (C), 166.7 (C). IR (neat): 1740, 1640, 1590. EIMS $m / z: 621(\mathrm{M}+\mathrm{H}), 385,329,236$. HRMS-EI $(\mathrm{m} / \mathrm{z})$ : $[\mathrm{M}]^{+}$calcd for $\mathrm{C}_{39} \mathrm{H}_{56} \mathrm{O}_{6}, 620.4077$; found, 620.4089 .

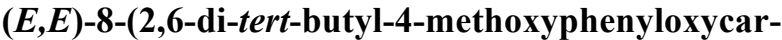
bonyl)oct-2,7-dienoic acid

A yellow oil (58 mg, 14\%): $R_{f}=0.1$ (hexane/ $\mathrm{Et}_{2} \mathrm{O}=$ 6/1). ${ }^{1} \mathrm{H}$ NMR: 1.33 (s, 18H), $1.74(\mathrm{~m}, 2 \mathrm{H}), 2.31(\mathrm{~m}$, $2 \mathrm{H}), 2.36(\mathrm{~m}, 2 \mathrm{H}), 3.79(\mathrm{~s}, 3 \mathrm{H}), 5.87(\mathrm{~d}, J=15.9,1 \mathrm{H})$, $6.11(\mathrm{~d}, J=15.9,1 \mathrm{H}), 6.86(\mathrm{~s}, 2 \mathrm{H}), 7.08(\mathrm{dt}, J=15.9$, $7.1,1 \mathrm{H}), 7.13(\mathrm{dt}, J=15.9,6.7,1 \mathrm{H}) .{ }^{13} \mathrm{C}$ NMR: 26.1 $\left(\mathrm{CH}_{2}\right), 31.3\left(\mathrm{CH}_{3}\right), 31.5\left(\mathrm{CH}_{2}\right), 31.6\left(\mathrm{CH}_{2}\right), 35.6(\mathrm{C})$, $55.2\left(\mathrm{CH}_{3}\right), 111.6(\mathrm{CH}), 121.4(\mathrm{CH}), 122.7(\mathrm{CH})$, $141.4(\mathrm{C}), 143.5(\mathrm{C}), 150.3(\mathrm{CH}), 150.7(\mathrm{CH}), 156.2$ (C), 166.8 (C), 171.5 (C). IR (neat): 1730, 1700, 1640. EIMS $m / z: 402\left(\mathrm{M}^{+}\right), 236$. HRMS-EI $(\mathrm{m} / \mathrm{z}):[\mathrm{M}]^{+}$ calcd for $\mathrm{C}_{24} \mathrm{H}_{34} \mathrm{O}_{5}, 402.2406$; found, 402.2393 .

General procedure for asymmetric conjugate addition cascade; $(1 S, 2 S, 3 S)$ - and $(1 R, 2 S, 3 S)$-tert-butyl 2-tert-butoxycarbonyl-3-phenylcyclohexaneacetate (tt-7a and $t c-7 a)$ (Table 1, entry 1)

To a solution of $\mathbf{1}(10.2 \mathrm{~g}, 42 \mathrm{mmol})$ in toluene (260 $\mathrm{mL}$ ) was added a solution of PhLi $(1.83 \mathrm{M} ; 16.4 \mathrm{~mL}$, $30 \mathrm{mmol})$ in cyclohexane- $\mathrm{Et}_{2} \mathrm{O}(7 / 3)$ at $-78{ }^{\circ} \mathrm{C}$, and the resulting solution was stirred for $20 \mathrm{~min}$ at the same temperature. A solution of $\mathbf{6 b}(2.96 \mathrm{~g}, 10 \mathrm{mmol})$ in toluene $(20 \mathrm{~mL})$ was added at $-78{ }^{\circ} \mathrm{C}$, and the mixture was stirred for $30 \mathrm{~min}$ at the same temperature. The reaction was quenched by the addition of saturated $\mathrm{NH}_{4} \mathrm{Cl}$. The organic layer was separated, and the aqueous layer was extracted with EtOAc. The combined organic layers were successively washed with saturated $\mathrm{NaHCO}_{3}$ and brine, dried over $\mathrm{Na}_{2} \mathrm{SO}_{4}$, and concentrated. Column chromatography (hexane/EtOAc $=20 / 1)$ gave $\boldsymbol{t t}-\mathbf{7 a}(1.86 \mathrm{~g}, 50 \%)$ with $71 \%$ ee and $\boldsymbol{t c}-\mathbf{7} \mathbf{a}(339 \mathrm{mg}, 9 \%)$ with $3 \%$ ee as white solids, and 1 (10.2 g, quantitative recovery) as a colorless solid.

$(1 S, 2 R, 3 S)$-tert-Butyl 2-(tert-butoxycarbonyl)-3butylcyclohexanacetate ( $t$ t-7b) (Table 1 , entry 4)

$R_{f}=0.6($ hexane/EtOAc $=9 / 1)$. A colorless oil. $86 \%$ ee (HPLC: Daicel Chiralcel OD-H, hexane $/ i-\mathrm{PrOH}=$ $1000 / 1,0.4 \mathrm{~mL} / \mathrm{min}, 230 \mathrm{~nm}$; major $14.5 \mathrm{~min}$, minor $17.5 \mathrm{~min}) .[\alpha]_{\mathrm{D}}{ }^{25}+12.1$ ( c 2.01 , benzene). ${ }^{1} \mathrm{H}$ NMR $\left(\mathrm{C}_{6} \mathrm{D}_{6}\right): 0.63-1.50(\mathrm{~m}, 10 \mathrm{H}), 0.88(\mathrm{t}, J=7.3,3 \mathrm{H}), 1.37$ 
(s, 9H), $1.38(\mathrm{~s}, 9 \mathrm{H}), 1.56(\mathrm{~m}, 1 \mathrm{H}), 1.66(\mathrm{~m}, 1 \mathrm{H}), 1.81$ $(\mathrm{t}, J=11.0,1 \mathrm{H}), 1.95(\mathrm{~m}, 1 \mathrm{H}), 2.11(\mathrm{dd}, J=10.0$, $15.0,1 \mathrm{H}), 2.25(\mathrm{~m}, 1 \mathrm{H}), 2.50(\mathrm{dd}, J=3.1,15.0,1 \mathrm{H})$. ${ }^{13} \mathrm{C} \mathrm{NMR}\left(\mathrm{C}_{6} \mathrm{D}_{6}\right): 14.2\left(\mathrm{CH}_{3}\right), 23.3\left(\mathrm{CH}_{2}\right), 25.7\left(\mathrm{CH}_{2}\right)$, $28.08\left(\mathrm{CH}_{3}\right), 28.11\left(\mathrm{CH}_{3}\right), 28.6\left(\mathrm{CH}_{2}\right), 30.8\left(\mathrm{CH}_{2}\right)$, $31.5\left(\mathrm{CH}_{2}\right), 34.5\left(\mathrm{CH}_{2}\right), 38.0\left(\mathrm{CH}_{2}\right), 40.1(\mathrm{CH}), 40.9$ $(\mathrm{CH}), 56.4(\mathrm{CH}), 79.6(\mathrm{C}), 79.7(\mathrm{C}), 171.4(\mathrm{C}), 174.3$ (C). IR (neat): 1730. EIMS $m / z: 355(\mathrm{M}+\mathrm{H}), 298$, 242. Anal. Calcd for $\mathrm{C}_{21} \mathrm{H}_{38} \mathrm{O}_{4}$ : C, 71.14; $\mathrm{H}, 10.80$. Found: C, 71.41; H, 11.04.

$(1 R, 2 R, 3 S)-$ tert-Butyl 2-(tert-butoxycarbonyl)-3butylcyclohexanacetate (tc-7b) (Table 1, entry 3)

$R_{f}=0.6($ hexane/EtOAc $=9 / 1)$. A colorless oil. $[\alpha]_{\mathrm{D}}{ }^{25}$ -15.5 (c $\left.0.51, \mathrm{CHCl}_{3}\right) .{ }^{1} \mathrm{H} \mathrm{NMR}: 0.88$ (t, $\left.J=7.0,3 \mathrm{H}\right)$, $1.01(\mathrm{~m}, 1 \mathrm{H}), 1.06(\mathrm{~m}, 1 \mathrm{H}), 1.28(\mathrm{~m}, 4 \mathrm{H}), 1.43(\mathrm{~s}, 9 \mathrm{H})$, $1.45(\mathrm{~s}, 9 \mathrm{H}), 1.47(\mathrm{~m}, 4 \mathrm{H}), 1.67(\mathrm{~m}, 2 \mathrm{H}), 1.80(\mathrm{~m}, 1 \mathrm{H})$, $2.24(\mathrm{dd}, J=4.3,8.6,1 \mathrm{H}), 2.28(\mathrm{dd}, J=9.5,15.3,1 \mathrm{H})$, $2.35(\mathrm{dd}, J=5.2,15.3,1 \mathrm{H}), 2.41(\mathrm{~m}, 1 \mathrm{H}) .{ }^{13} \mathrm{C}$ NMR: $14.1\left(\mathrm{CH}_{3}\right), 20.1\left(\mathrm{CH}_{2}\right), 22.9\left(\mathrm{CH}_{2}\right), 28.08\left(\mathrm{CH}_{3}\right)$, $28.11\left(\mathrm{CH}_{3}\right), 29.0\left(\mathrm{CH}_{2}\right), 29.1\left(\mathrm{CH}_{2}\right), 29.2\left(\mathrm{CH}_{2}\right), 32.3$ $(\mathrm{CH}), 33.7\left(\mathrm{CH}_{2}\right), 34.0\left(\mathrm{CH}_{2}\right), 36.1(\mathrm{CH}), 51.5(\mathrm{CH})$, 80.0 (C), 172.6 (C), 174.0 (C). IR (neat): 1720. EIMS $m / z: 355(\mathrm{M}+\mathrm{H}), 298,242$. Anal. Calcd for $\mathrm{C}_{21} \mathrm{H}_{38} \mathrm{O}_{4}$ : C, 71.14; H, 10.80. Found: C, 70.97; H, 10.52 .

(S,E)-Bis(2,6-di-tert-butyl-4-methoxyphenyl)

5phenylnona-2-enedioate (9a) (eq 1)

$R_{f}=0.3$ (hexane/Et ${ }_{2} \mathrm{O}=4 / 1$ ). $87 \%$ ee (HPLC: Daicel Chiralpak AD-H, hexane $/ i-\mathrm{PrOH}=100 / 1,0.5 \mathrm{~mL} / \mathrm{min}$, $254 \mathrm{~nm}$; minor $39.4 \mathrm{~min}$, major $42.8 \mathrm{~min}$ ). The absolute configuration was tentatively assigned by analogy. The yield was based on ${ }^{1} \mathrm{H}$ NMR and the specific rotation was not measured because 9a was inseparable from chiral ligand $\mathbf{1}$. The structure was identified by comparing its ${ }^{1} \mathrm{H}$ and ${ }^{13} \mathrm{C}$ NMR with those of $( \pm)-9 \mathbf{a}$ that was prepared from $\mathbf{6 a}$ and phenyllithium (1.5 equiv) without 1 in THF at $-78^{\circ} \mathrm{C}$ and fully characterized: ${ }^{1} \mathrm{H}$ NMR: 1.06 (s, 9H), 1.29 (s, 9H), 1.30 (m, 9H), $1.32(\mathrm{~m}, 9 \mathrm{H}), 1.37(\mathrm{~m}, 1 \mathrm{H}), 1.43(\mathrm{~m}, 1 \mathrm{H}), 1.75$ $(\mathrm{m}, 1 \mathrm{H}), 1.86(\mathrm{~m}, 1 \mathrm{H}), 2.26(\mathrm{~m}, 2 \mathrm{H}), 2.90(\mathrm{dd}, J=6.1$, $17.7,1 \mathrm{H}), 2.97(\mathrm{dd}, J=7.6,17.7,1 \mathrm{H}), 3.23(\mathrm{~m}, 1 \mathrm{H})$, $3.76(\mathrm{~s}, 3 \mathrm{H}), 3.79(\mathrm{~s}, 3 \mathrm{H}), 6.00(\mathrm{~d}, J=15.9,1 \mathrm{H}), 6.79$ $(\mathrm{d}, J=3.1,1 \mathrm{H}), 6.83(\mathrm{~d}, J=3.1,1 \mathrm{H}), 6.85(\mathrm{~s}, 2 \mathrm{H})$, $7.06(\mathrm{dt}, J=15.9,6.7,1 \mathrm{H}), 7.20-7.31(\mathrm{~m}, 5 \mathrm{H}) .{ }^{13} \mathrm{C}$ NMR: $25.6\left(\mathrm{CH}_{2}\right), 31.0\left(\mathrm{CH}_{3}\right), 31.3\left(\mathrm{CH}_{3}\right), 32.1\left(\mathrm{CH}_{2}\right)$, $35.2(\mathrm{C}), 35.4(\mathrm{C}), 35.46\left(\mathrm{CH}_{2}\right), 35.51(\mathrm{C}), 40.8(\mathrm{CH})$, $43.0\left(\mathrm{CH}_{2}\right), 55.1\left(\mathrm{CH}_{3}\right), 111.5(\mathrm{CH}), 122.1(\mathrm{CH})$, $126.6(\mathrm{CH}), 127.8(\mathrm{CH}), 128.5(\mathrm{CH}), 143.2(\mathrm{C}), 143.4$ (C), $143.45(\mathrm{C}), 143.48(\mathrm{C}), 151.2(\mathrm{CH}), 156.1$ (C), $166.8(\mathrm{C}), 172.3(\mathrm{C})$. IR $\left(\mathrm{CHCl}_{3}\right): 1750,1730,1650$, 1590. FABMS $m / z$ : $699(\mathrm{M}+\mathrm{H}), 463$. Anal. calcd for $\mathrm{C}_{45} \mathrm{H}_{62} \mathrm{O}_{6}$ : C, 77.33; H, 8.94. Found: C, 77.09; H, 8.94.

Conjugate addition cascade in the absence of chiral ligand in THF (eq 2 and note 16); Di-tert-butyl 3,7diphenylnonandioate (10a)

A $1.73 \mathrm{M}$ cyclohexane- $\mathrm{Et}_{2} \mathrm{O}$ solution of $\mathrm{PhLi}$ (17.3 $\mathrm{mL}, 30 \mathrm{mmol})$ was diluted with THF $(260 \mathrm{~mL})$, and to the solution, was added a solution of $\mathbf{6 b}(2.96 \mathrm{~g}, 10$ $\mathrm{mmol})$ in THF $(40 \mathrm{~mL})$ at $-78^{\circ} \mathrm{C}$. After $0.5 \mathrm{~h}, \mathrm{MeOH}$ $(10 \mathrm{~mL})$ and saturated $\mathrm{NH}_{4} \mathrm{Cl}(200 \mathrm{~mL})$ were successively added. The mixture was extracted with EtOAc. The organic layer was washed with saturated $\mathrm{NaHCO}_{3}$ and brine, and then dried over $\mathrm{Na}_{2} \mathrm{SO}_{4}$. Concentration followed by column chromatography (hexane/EtOAc $=15 / 1)$ gave $( \pm)-\boldsymbol{t t}-\mathbf{7 a}(344 \mathrm{mg}, 9 \%)$ and $( \pm)-\boldsymbol{t c}-\mathbf{7 a}$ $(138 \mathrm{mg}, 4 \%)$ as white solids, and the title compound (3.57 g, 79\%) as a colorless oil: $R_{f}=0.4$ (hexane/ EtOAc $=9 / 1) .1 \mathrm{H} \mathrm{NMR:} \mathrm{1.00-1.05} \mathrm{(m,} \mathrm{2H),} 1.27(\mathrm{~s}$, $18 \mathrm{H}), 1.51-1.63(\mathrm{~m}, 4 \mathrm{H}), 2.40(\mathrm{dd}, J=8.6,15.0,2 \mathrm{H})$, $2.47(\mathrm{dd}, J=7.0,15.0,2 \mathrm{H}), 2.94(\mathrm{~m}, 2 \mathrm{H}),, 7.07-7.29$ (m, 10H). ${ }^{13} \mathrm{C}$ NMR: $24.7\left(\mathrm{CH}_{2}\right), 24.9\left(\mathrm{CH}_{2}\right), 27.9$ $\left(\mathrm{CH}_{3}\right), 36.2\left(\mathrm{CH}_{2}\right), 42.18(\mathrm{CH}), 42.23(\mathrm{CH}), 42.9$ $\left(\mathrm{CH}_{2}\right), 43.0\left(\mathrm{CH}_{2}\right), 80.1(\mathrm{C}), 126.21(\mathrm{CH}), 126.24$ $(\mathrm{CH}), 127.50(\mathrm{CH}), 127.52(\mathrm{CH}), 128.18(\mathrm{CH})$, $128.21(\mathrm{CH}), 144.0(\mathrm{C}), 144.1$ (C), $171.6(\mathrm{C}), 171.7$ (C). IR (neat): 1730. FABMS $m / z: 453(\mathrm{M}+\mathrm{H})$. HRMS-FAB $(\mathrm{m} / z)$ : $[\mathrm{M}+\mathrm{H}]^{+}$calcd for $\mathrm{C}_{29} \mathrm{H}_{41} \mathrm{O}_{4}$, 453.3005; found, 453.2998.

Alternative method (note 16): To a solution of $\mathbf{6 b}$ (296 mg, $1.0 \mathrm{mmol})$ in THF $(30 \mathrm{~mL})$ was added a 1.83 $\mathrm{M}$ cyclohexane- $\mathrm{Et}_{2} \mathrm{O}$ solution of $\mathrm{PhLi}(1.07 \mathrm{~mL}, 2.0$ $\mathrm{mmol})$ at $-78{ }^{\circ} \mathrm{C}$. After $0.5 \mathrm{~h}, \mathrm{MeOH}(1 \mathrm{~mL})$ and saturated $\mathrm{NH}_{4} \mathrm{Cl}(40 \mathrm{~mL})$ were successively added. The mixture was extracted with EtOAc. The organic layer was washed with saturated $\mathrm{NaHCO}_{3}$ and brine, and dried over $\mathrm{Na}_{2} \mathrm{SO}_{4}$. Concentration followed by column chromatography (hexane/EtOAc $=20 / 1$ ) gave $( \pm)-t t-7 \mathbf{a}(197 \mathrm{mg}, 52 \%)$ and $( \pm)-t c-7 \mathbf{a}(16 \mathrm{mg}, 5 \%)$ as white solids, and $\mathbf{1 0 a}(37 \mathrm{mg}, 8 \%)$ as a colorless oil. Recrystallization of $( \pm)-\mathbf{t t}-\mathbf{7 a}$ from $\mathrm{MeOH}$ gave colorless needles of $\mathrm{mp} 82-83^{\circ} \mathrm{C}$.

Preparation of monophenyl adducts $9 \mathrm{~b}$ and 9c (Scheme 3); (E)-tert-butyl 7-(tetrahydro-2H-pyran2-yloxy)hept-2-enoate (12)

To a solution of (E)-tert-butyl 7-hydroxyhept-2enoate $(\mathbf{1 1})^{17}(2.22 \mathrm{~g}, 11 \mathrm{mmol})$ in dry $\mathrm{CHCl}_{3}(45 \mathrm{~mL})$ were added 3,4-dihydro-2 $H$-pyran $(1.5 \mathrm{~mL}, 17 \mathrm{mmol})$ and then PPTS $(280 \mathrm{mg}, 1.1 \mathrm{mmol})$ in $\mathrm{CHCl}_{3}(5 \mathrm{~mL})$. The mixture was stirred for $14 \mathrm{~h}$ at $\mathrm{rt}$, and diluted with $\mathrm{Et}_{2} \mathrm{O}(60 \mathrm{~mL})$. The whole was washed with half saturated $\mathrm{NaCl}(80 \mathrm{~mL})$. The organic layer was dried over $\mathrm{Na}_{2} \mathrm{SO}_{4}$ and concentrated in vacuo, and the resulting colorless oil (3.09 g) was purified by column chromatography (hexane/AcOEt $=3 / 1$ ) to give the title compound (3.02 g, 96\%) as a colorless oil: $R_{f}=0.7$ (hexane/AcOEt = 2/1). ${ }^{1} \mathrm{H}$ NMR: $1.48(\mathrm{~s}, 9 \mathrm{H}), 1.50-1.62$ $(\mathrm{m}, 8 \mathrm{H}), 1.71(\mathrm{~m}, 1 \mathrm{H}), 1.83(\mathrm{~m}, 1 \mathrm{H}), 2.21(\mathrm{~m}, 2 \mathrm{H})$, $3.39(\mathrm{~m}, 1 \mathrm{H}), 3.50(\mathrm{~m}, 1 \mathrm{H}), 3.75(\mathrm{~m}, 1 \mathrm{H}), 3.86(\mathrm{~m}$, $1 \mathrm{H}), 4.57(\mathrm{~m}, 1 \mathrm{H}), 5.75(\mathrm{~d}, J=15.6,1 \mathrm{H}), 6.86(\mathrm{dt}, J=$ 15.6, 7.0, 1H). ${ }^{13} \mathrm{C}$ NMR: $19.6\left(\mathrm{CH}_{2}\right), 24.8\left(\mathrm{CH}_{2}\right)$, $25.4\left(\mathrm{CH}_{2}\right), 28.1\left(\mathrm{CH}_{3}\right), 29.2\left(\mathrm{CH}_{2}\right), 30.7\left(\mathrm{CH}_{2}\right), 31.8$ $\left(\mathrm{CH}_{2}\right), 62.3\left(\mathrm{CH}_{2}\right), 67.1\left(\mathrm{CH}_{2}\right), 79.9(\mathrm{C}), 98.8(\mathrm{CH})$, $123.1(\mathrm{CH}), 147.6(\mathrm{CH}), 166.0(\mathrm{C})$. IR (neat): 1710, 1650. EIMS m/z: $283(\mathrm{M}-\mathrm{H}), 227$. Anal. calcd for $\mathrm{C}_{16} \mathrm{H}_{28} \mathrm{O}_{4}$ : C, 67.57; H, 9.92. Found: C, 67.61; H, 10.15 .

tert-Butyl 7-hydroxy-3-phenylheptanoate (13) 
To a solution of PhLi (1.45 M; $2.1 \mathrm{~mL}, 3.0 \mathrm{mmol})$ in dry THF $(8 \mathrm{~mL})$ was added a solution of $12(284 \mathrm{mg}$, $1.0 \mathrm{mmol})$ in dry THF $(2 \mathrm{~mL})$ at $-78^{\circ} \mathrm{C}$. The mixture was stirred for $30 \mathrm{~min}$ at the same temperature, and $\mathrm{MeOH}(2 \mathrm{~mL})$ and then saturated $\mathrm{NH}_{4} \mathrm{Cl}(20 \mathrm{~mL})$ were added. The whole was extracted with AcOEt (20 $\mathrm{mL} \times 3)$, and the combined organic layers were washed with saturated $\mathrm{NaHCO}_{3}(40 \mathrm{~mL})$ and brine $(40$ $\mathrm{mL}$ ), dried over $\mathrm{Na}_{2} \mathrm{SO}_{4}$, and concentrated in vacuo to give yellow oil (432 mg) including a phenyl adduct. To a solution of the yellow oil in EtOH $(8 \mathrm{~mL})$ was added PPTS (25 mg, $0.1 \mathrm{mmol}$ ). After stirred for $12 \mathrm{~h}$ at $50{ }^{\circ} \mathrm{C}$, the mixture was concentrated in vacuo and diluted with $\mathrm{H}_{2} \mathrm{O}(40 \mathrm{~mL})$. The whole was extracted with $\mathrm{Et}_{2} \mathrm{O}(30 \mathrm{~mL} \times 3)$, and the combined organic layers were washed with brine $(40 \mathrm{~mL})$, dried over $\mathrm{Na}_{2} \mathrm{SO}_{4}$, and concentrated in vacuo to give yellow oil (335 mg), which was purified by column chromatography (hexane/AcOEt $=2 / 1$ ) to give the title compound (254 mg, 91\% over 2 steps) as a colorless oil: $R_{f}=0.1$ (hexane/AcOEt $\left.=5 / 1\right) .{ }^{1} \mathrm{H}$ NMR: $1.21-1.27$ $(\mathrm{m}, 2 \mathrm{H}), 1.30(\mathrm{~s}, 9 \mathrm{H}), 1.49-1.67(\mathrm{~m}, 4 \mathrm{H}), 1.60(\mathrm{~s}, 1 \mathrm{H})$, $2.47(\mathrm{dd}, J=8.3,14.7,1 \mathrm{H}), 2.54(\mathrm{dd}, J=7.3,14.7$, $1 \mathrm{H}), 3.03(\mathrm{~m}, 1 \mathrm{H}), 3.57(\mathrm{t}, J=6.4,2 \mathrm{H}), 7.18-7.28(\mathrm{~m}$, 5H). ${ }^{13} \mathrm{C}$ NMR: $23.4\left(\mathrm{CH}_{2}\right), 27.8\left(\mathrm{CH}_{3}\right), 32.5\left(\mathrm{CH}_{2}\right)$, $36.0\left(\mathrm{CH}_{2}\right), 42.4(\mathrm{CH}), 42.9\left(\mathrm{CH}_{2}\right), 62.6\left(\mathrm{CH}_{2}\right), 80.2$ (C), $126.3(\mathrm{CH}), 127.5(\mathrm{CH}), 128.2(\mathrm{CH}), 143.9(\mathrm{C})$, 171.7 (C). IR (neat): 3400, 1720. EIMS m/z: $222(\mathrm{M}+$ $\mathrm{H}-t$-Bu), 205. Anal. calcd for $\mathrm{C}_{17} \mathrm{H}_{26} \mathrm{O}_{3}: \mathrm{C}, 73.34 ; \mathrm{H}$, 9.41. Found: C, 73.54; H, 9.62.

\section{tert-Butyl 7-formyl-3-phenylhexanoate (14)}

To a solution of $\mathbf{1 3}$ (27.9 g, $0.10 \mathrm{~mol})$ in dry toluene and DMSO (330 mL each), were added pyridine (8.1 $\mathrm{mL}, 0.10 \mathrm{~mol})$, TFA (3.9 $\mathrm{mL}, 0.050 \mathrm{~mol})$, and then DCC (62 $\mathrm{g}, 0.30 \mathrm{~mol})$ at $\mathrm{rt}$. The mixture was stirred for $18 \mathrm{~h}$ at $\mathrm{rt}$, diluted with toluene $(1 \mathrm{~L})$, and filtered. The filtrate was washed with $\mathrm{H}_{2} \mathrm{O}(1 \mathrm{~L} \times 2)$ and brine $(1 \mathrm{~L})$, dried over $\mathrm{Na}_{2} \mathrm{SO}_{4}$, and concentrated in vacuo to give yellow oil (76.8 g), which was purified by column chromatography (hexane/ AcOEt $=10 / 1$ ) to give the title compound $(24 \mathrm{~g}, 87 \%)$ as a colorless oil: $R_{f}=0.5$ (hexane/AcOEt $\left.=3 / 1\right) .{ }^{1} \mathrm{H}$ NMR: $1.30(\mathrm{~s}, 9 \mathrm{H})$, $1.45-1.70(\mathrm{~m}, 4 \mathrm{H}), 2.37(\mathrm{~m}, 2 \mathrm{H}), 2.48(\mathrm{dd}, J=8.3$, 15.0, 1H), 2.54 (dd, $J=7.4,14.7,1 \mathrm{H}), 3.04(\mathrm{~m}, 1 \mathrm{H})$, 7.18-7.29 (m, 5H), 9.68 (s, 1H). ${ }^{13} \mathrm{C}$ NMR: 19.9 $\left(\mathrm{CH}_{2}\right), 27.8\left(\mathrm{CH}_{3}\right), 35.5\left(\mathrm{CH}_{2}\right), 42.3(\mathrm{CH}), 42.8\left(\mathrm{CH}_{2}\right)$, $43.6\left(\mathrm{CH}_{2}\right), 80.3(\mathrm{C}), 126.5(\mathrm{CH}), 127.5(\mathrm{CH}), 128.4$ $(\mathrm{CH}), 143.4(\mathrm{C}), 171.4(\mathrm{C}), 202.3(\mathrm{CH})$. IR (neat): 1730, 1710. EIMS $m / z: 220(\mathrm{M}+\mathrm{H}-t$-Bu). Anal. calcd for $\mathrm{C}_{17} \mathrm{H}_{24} \mathrm{O}_{3}$ : C, 73.88; $\mathrm{H}, 8.75$. Found: $\mathrm{C}$, 73.62; H, 8.88.

\section{(E)-Di-tert-butyl 7-phenylnona-2-enedioate (9b)}

To a suspension of tert-butyl triphenylphosphoranylideneacetate $(40 \mathrm{~g}, 0.11 \mathrm{~mol})$ in toluene $(140 \mathrm{~mL})$ was added a solution of $14(24.0 \mathrm{~g}, 87 \mathrm{mmol})$ in toluene $(40 \mathrm{~mL})$ over $10 \mathrm{~min}$. The mixture was stirred for $16 \mathrm{~h}$ at $\mathrm{rt}$, diluted with hexane $(100 \mathrm{~mL})$, and filtered. Concentration of the filtrate in vacuo gave yellow oil (34.7 g), which was purified by column chromatography
(hexane/AcOEt $=20 / 1$ ) to give the title compound $(E: Z=97: 3 ; 28.4 \mathrm{~g}, 88 \%)$ as a colorless oil: $R_{f}=0.6$ (hexane/AcOEt $=4 / 1) .{ }^{1} \mathrm{H}$ NMR: $1.27(\mathrm{~m}, 1 \mathrm{H}), 1.30(\mathrm{~s}$, $9 \mathrm{H}), 1.46(\mathrm{~s}, 9 \mathrm{H}), 1.60(\mathrm{~m}, 1 \mathrm{H}), 1.65(\mathrm{~m}, 2 \mathrm{H}), 2.11(\mathrm{~m}$, $2 \mathrm{H},), 2.47(\mathrm{dd}, J=8.3,14.7,1 \mathrm{H}), 2.52(\mathrm{dd}, J=7.0$, $14.7,1 \mathrm{H}), 3.02(\mathrm{~m}, 1 \mathrm{H}), 5.67(\mathrm{~d}, J=15.6,1 \mathrm{H}), 6.76$ $(\mathrm{dt}, J=15.6,7.6,1 \mathrm{H}), 7.15-7.30(\mathrm{~m}, 5 \mathrm{H}) .{ }^{13} \mathrm{C}$ NMR: $25.8\left(\mathrm{CH}_{2}\right), 27.9\left(\mathrm{CH}_{3}\right), 28.1\left(\mathrm{CH}_{3}\right), 31.8\left(\mathrm{CH}_{2}\right), 35.7$ $\left(\mathrm{CH}_{2}\right), 42.3(\mathrm{CH}), 42.9\left(\mathrm{CH}_{2}\right), 79.9(\mathrm{C}), 80.2(\mathrm{C})$, $123.1(\mathrm{CH}), 126.4(\mathrm{CH}), 127.5(\mathrm{CH}), 128.3(\mathrm{CH})$, 143.7 (C), 147.4 (CH), 165.9 (C), 171.5 (C). IR (neat): 1720, 1650. EIMS m/z: $375(\mathrm{M}+\mathrm{H}), 340,318$. Anal. calcd for $\mathrm{C}_{23} \mathrm{H}_{34} \mathrm{O}_{4}$ : C, 73.76; H, 9.15. Found: C, 74.04; H, 9.31.

\section{(E)-Dimethyl 7-phenylnona-2-enedioate (9c)}

To a solution of $9 \mathbf{b}(374 \mathrm{mg}, 1.0 \mathrm{mmol})$ in $\mathrm{MeOH}$ (12 $\mathrm{mL})$ was added conc. $\mathrm{H}_{2} \mathrm{SO}_{4}(0.05 \mathrm{~mL})$ at $\mathrm{rt}$. The mixture was heated under reflux for $2 \mathrm{~h}$ and neutralized by the addition of $10 \% \mathrm{Na}_{2} \mathrm{CO}_{3}(0.5 \mathrm{~mL})$. The whole was extracted with $\mathrm{Et}_{2} \mathrm{O}(30 \mathrm{~mL} \times 3)$, and the combined organic layers were washed with brine (40 $\mathrm{mL}$ ), dried over $\mathrm{Na}_{2} \mathrm{SO}_{4}$, and concentrated in vacuo to give the title compound (280 $\mathrm{mg}, 97 \%)$ as a yellow oil: $R_{f}=0.5$ (hexane/AcOEt $\left.=3 / 1\right)$. ${ }^{1} \mathrm{H}$ NMR: $1.28(\mathrm{~m}$, $1 \mathrm{H}), 1.33(\mathrm{~m}, 1 \mathrm{H}), 1.65(\mathrm{~m}, 2 \mathrm{H}), 2.14(\mathrm{~m}, 2 \mathrm{H}), 2.58$ (dd, $J=8.0,15.6,1 \mathrm{H}), 2.62(\mathrm{dd}, J=7.3,15.6,1 \mathrm{H})$, $3.09(\mathrm{~m}, 1 \mathrm{H}), 3.58(\mathrm{~s}, 3 \mathrm{H}), 3.71(\mathrm{~s}, 3 \mathrm{H}), 5.75(\mathrm{~d}, J=$ $15.6,1 \mathrm{H}), 6.87(\mathrm{dt}, J=15.6,7.1,1 \mathrm{H}), 7.15-7.31(\mathrm{~m}$, 5H). ${ }^{13} \mathrm{C}$ NMR: $25.7\left(\mathrm{CH}_{2}\right), 31.9\left(\mathrm{CH}_{2}\right), 35.4\left(\mathrm{CH}_{2}\right)$, $41.5\left(\mathrm{CH}_{2}\right), 41.9(\mathrm{CH}), 51.3\left(\mathrm{CH}_{3}\right), 51.4\left(\mathrm{CH}_{3}\right), 121.0$ $(\mathrm{CH}), 126.5(\mathrm{CH}), 127.3(\mathrm{CH}), 128.5(\mathrm{CH}), 143.5(\mathrm{C})$, $149.0(\mathrm{CH}), 166.9(\mathrm{C}), 172.6(\mathrm{C})$. IR (neat): 1740, 1720, 1660. EIMS $m / z: 290\left(\mathrm{M}^{+}\right)$, 258. Anal. calcd for $\mathrm{C}_{17} \mathrm{H}_{22} \mathrm{O}_{4}$ : C, 70.32; H, 7.64. Found: C, 70.51; H, 7.64.

\section{Cyclization of 9b (Scheme 4)}

To a solution of $i-\operatorname{Pr}_{2} \mathrm{NH}(0.17 \mathrm{~mL}, 1.2 \mathrm{mmol})$ in dry THF $(3 \mathrm{~mL})$ were added a $1.56 \mathrm{M}$ hexane solution of $\operatorname{BuLi}(0.77 \mathrm{~mL}, 1.2 \mathrm{mmol})$ and, after $20 \mathrm{~min}$, a solution of $9 \mathbf{b}(374 \mathrm{mg}, 1.0 \mathrm{mmol})$ in dry THF $(2 \mathrm{~mL})$ at $78{ }^{\circ} \mathrm{C}$ under argon atmosphere. The mixture was stirred for $15 \mathrm{~min}$ at the same temperature, and $\mathrm{MeOH}$ $(10 \mathrm{~mL})$ and then saturated $\mathrm{NH}_{4} \mathrm{Cl}(40 \mathrm{~mL})$ were added. The whole was extracted with AcOEt $(30 \mathrm{~mL} \times 3)$. The combined organic layers were washed with $10 \%$ $\mathrm{HCl}(40 \mathrm{~mL}), \mathrm{H}_{2} \mathrm{O}(40 \mathrm{~mL})$, saturated $\mathrm{NaHCO}_{3}(40$ $\mathrm{mL}$ ), and brine $(40 \mathrm{~mL})$, dried over $\mathrm{Na}_{2} \mathrm{SO}_{4}$, and concentrated in vacuo to give a pale yellow solid (388 g), which was purified by column chromatography (hexane/AcOEt $=9 / 1)$ to give a $7: 3$ mixture of $\boldsymbol{t t}-\mathbf{7} \mathbf{a}$ and tc-7a (351 mg, 94\%) as a white solid.

\section{Cyclization of 9c (Scheme 4)}

The above procedure using 9c $(290 \mathrm{mg}, 1.0 \mathrm{mmol})$ and purification by column chromatography (hexane/ $\mathrm{AcOEt}=5 / 1)$ gave an 18:82 mixture of $\boldsymbol{t} \boldsymbol{t}-\mathbf{7 e}$ and $\boldsymbol{t c}-\mathbf{7 e}$ (266 mg, 92\%) as a white solid.

The compounds $\boldsymbol{t} \boldsymbol{t}-\mathbf{7 e}$ and $\boldsymbol{t c}-\mathbf{7 e}$ were inseparable and characterized by being prepared from $t t-7 \mathbf{a}$ and $t c-7 \mathbf{a}$, respectively. 


\section{$(1 R, 2 S, 3 S)$-Methyl 2-(methoxycarbonyl)-3-phenyl-} cyclohexaneacetate $(t c-7 \mathrm{e})$

To TFA ( $3.4 \mathrm{~mL}, 45 \mathrm{mmol})$ was added $\boldsymbol{t c}-7 \mathbf{a}(167 \mathrm{mg}$, $0.45 \mathrm{mmol}$ ) at $\mathrm{rt}$. The mixture was stirred for $0.5 \mathrm{~h}$ at rt and concentrated in vacuo to give a white solid, which was dissolved in $\mathrm{MeOH}(20 \mathrm{~mL})$. To the solution was added a solution of $\mathrm{CH}_{2} \mathrm{~N}_{2}$ in $\mathrm{Et}_{2} \mathrm{O}$ until no more $\mathrm{N}_{2}$ gas evolved. To the yellow solution was added HOAc (10 drops), and the whole was concentrated. The resulting residue was purified by column chromatography (hexane/EtOAc $=4 / 1$ ) to give the title compound (129 $\mathrm{mg}, 99 \%)$ as a white solid of $\mathrm{mp}$ $62-64{ }^{\circ} \mathrm{C}: R_{f}=0.4$ (hexane/EtOAc $\left.=4 / 1\right) .3 \%$ ee (HPLC: Daicel Chiralcel OJ, hexane $/ i-\mathrm{PrOH}=100 / 1$, $0.5 \mathrm{~mL} / \mathrm{min}, 254 \mathrm{~nm}$; major $30.0 \mathrm{~min}$, minor 36.0 $\min ) . \quad[\alpha]_{\mathrm{D}}{ }^{25}-12.2\left(c \quad 1.12, \mathrm{CHCl}_{3}\right) .{ }^{1} \mathrm{H} \quad \mathrm{NMR}$ $\left(\mathrm{CD}_{3} \mathrm{OD}\right): 1.45(\mathrm{~m}, 1 \mathrm{H}), 1.61(\mathrm{~m}, 2 \mathrm{H}), 1.70(\mathrm{~m}, 1 \mathrm{H})$, $1.73(\mathrm{~m}, 1 \mathrm{H}), 1.83(\mathrm{~m}, 1 \mathrm{H}), 2.50(\mathrm{dd}, J=7.7,16.2$, $1 \mathrm{H}), 2.63(\mathrm{dd}, J=6.5,16.2,1 \mathrm{H}), 2.73(\mathrm{~m}, 1 \mathrm{H}), 2.91$ $(\mathrm{dt}, J=4.0,12.2,1 \mathrm{H}), 3.00(\mathrm{dd}, J=4.0,12.2,1 \mathrm{H})$, $3.37(\mathrm{~s}, 3 \mathrm{H}), 3.64(\mathrm{~s}, 3 \mathrm{H}), 7.12-7.22(\mathrm{~m}, 5 \mathrm{H}) .{ }^{13} \mathrm{C}$ NMR ( $\left.\mathrm{CD}_{3} \mathrm{OD}\right): 21.7\left(\mathrm{CH}_{2}\right), 31.5\left(\mathrm{CH}_{2}\right), 34.0(\mathrm{CH})$, $34.2\left(\mathrm{CH}_{2}\right), 35.9\left(\mathrm{CH}_{2}\right), 41.8(\mathrm{CH}), 51.8\left(\mathrm{CH}_{3}\right), 52.1$ $\left(\mathrm{CH}_{3}\right), 52.6(\mathrm{CH}), 127.3(\mathrm{CH}), 128.4(\mathrm{CH}), 129.3$ (CH), 146.1 (C), 175.0 (C), 175.7 (C). IR (Nujol): 1720. EIMS $m / z$ : $290\left(\mathrm{M}^{+}\right), 259,230$. Anal. Calcd for $\mathrm{C}_{17} \mathrm{H}_{22} \mathrm{O}_{4}$ : C, 70.32; H, 7.64. Found: C, 70.30; H, 7.61.

Methyl (1S,2S,3S)-2-(Methoxycarbonyl)-3-phenylcyclohexaneacetate $(t t-7 \mathrm{e})$

The same procedure as that from $\boldsymbol{t c}-\mathbf{7 a}$ to $\boldsymbol{t c}-\mathbf{7 e}$ gave $\boldsymbol{t} \boldsymbol{t}-\mathbf{7 e}$ with $71 \%$ ee in $96 \%$ yield from $\boldsymbol{t t}-\mathbf{7 a}$ with $71 \%$ ee as colorless oil: $[\alpha]_{\mathrm{D}}^{25}+23.2\left(c 1.08, \mathrm{CHCl}_{3}\right)$. The ee was determined by HPLC (Daicel Chiralcel OJ, hexane $/ \mathrm{PrOH}=100 / 1,0.5 \mathrm{~mL} / \mathrm{min}, 254 \mathrm{~nm}$; minor $30.0 \mathrm{~min}$, major $42.7 \mathrm{~min}$ ).

A colorless oil. $R_{f}=0.4($ hexane $/ \mathrm{AcOEt}=4 / 1) .{ }^{1} \mathrm{H}$ NMR: $1.16(\mathrm{~m}, 1 \mathrm{H}), 1.52(\mathrm{~m}, 2 \mathrm{H}), 1.87(\mathrm{~m}, 2 \mathrm{H}), 1.93$ $(\mathrm{m}, 1 \mathrm{H}), 2.16(\mathrm{dd}, J=8.9,14.7,1 \mathrm{H}), 2.23(\mathrm{~m}, 1 \mathrm{H})$, $2.33(\mathrm{dd}, J=3.4,14.7,1 \mathrm{H}), 2.38(\mathrm{t}, J=11.3,1 \mathrm{H})$, $2.82(\mathrm{dt}, J=3.4,11.3,1 \mathrm{H}), 3.35(\mathrm{~s}, 3 \mathrm{H}), 3.67(\mathrm{~s}, 3 \mathrm{H})$, 7.15-7.27 (m, 5H) ${ }^{13} \mathrm{C}$ NMR: $25.5\left(\mathrm{CH}_{2}\right), 31.2\left(\mathrm{CH}_{2}\right)$, $33.4\left(\mathrm{CH}_{2}\right), 37.1(\mathrm{CH}), 39.4\left(\mathrm{CH}_{2}\right), 47.4(\mathrm{CH}), 51.1$ $\left(\mathrm{CH}_{3}\right), 51.5\left(\mathrm{CH}_{3}\right), 55.9(\mathrm{CH}), 126.5(\mathrm{CH}), 127.2$ $(\mathrm{CH}), 128.3(\mathrm{CH}), 143.7(\mathrm{C}), 172.4(\mathrm{C}), 174.4(\mathrm{C}) . \mathrm{IR}$ (neat): 1740, 1720. EIMS m/z: $290\left(\mathrm{M}^{+}\right), 259,230$. Anal. calcd for $\mathrm{C}_{17} \mathrm{H}_{22} \mathrm{O}_{4}$ : C, 70.32; H, 7.64. Found: C, $70.20 ; \mathrm{H}, 7.50$.

\section{Acknowledgment}

We thank JSPS and MEXT for financial support.

Supporting Information for this article is available online at http://www.thieme-connect.com/products/ ejournals/journal/10.1055/s-00000084.

\section{References}

(1) (a) Tomioka, K. Synthesis 1990, 541-549. (b) Kanai, M.; Shibasaki, M. In Catalytic Asymmetric Synthesis; Ojima, I., ed: VCH: Weinheim, 2000, p. 569. (c) Sibi,
M. P.; Manyem, S. Tetrahedron 2000, 56, 8033-8061. (d) Krause, N.; Hoffmann-Röder, A. Synthesis 2001, 171-196. (e) Feringa, B. L.; Naasz, R.; Imbos, R.; Arnold, L. A. In Modern Organocopper Chemistry; Krause, N., ed.; Wiley-VCH: Weinheim, 2002, chapter 7. (f) Hayashi, T.; Yamasaki, K. Chem. Rev. 2003, 103, 2829-2844. (g) Tomioka, K. In Comprehensive Asymmetric Catalysis, Supplement; Jacobsen, E. N., Pfaltz, A., Yamamoto, H., Eds.; Springer, 2004; Chapter 31.1, pp 109-124. (h) Yamataka, H.; Yamada, K.; Tomioka, K. In The Chemistry of Organolithium Compounds; Rappoport, Z., Marek, I., Eds; Wiley, 2004; Part 1, Chapter 14. (i) Christoffers, J.; Koripelly, G.; Rosiak, A.; Rössle, M. Synthesis 2007, 1279-1300. (j) Tomioka, K.; Yamamoto, Y.; Yamada, K. In Comprehensive Chirality; Carreira, E. M., Yamamoto, H., Eds.; Elsevier, 2012; Vol. 4, pp 122-131.

(2) (a) Asao, N.; Uyehara, T.; Yamamoto, Y. Tetrahedron 1990, 46, 4563-4572. (b) Suzuki, I.; Kin, H.; Yamamoto, Y. J. Am. Chem. Soc. 1993, 115, 10139-10146. (c) Shida, N.; Kabuto, C.; Niwa, T.; Ebata, T.; Yamamoto, Y. J. Org. Chem. 1994, 59, 4068-4075. (d) Börner, C.; König, W. A.; Woodward, S. Tetrahedron Lett. 2001, 42, 327-329. (e) Cardillo, G.; Gentilucci, L.; Gianotti, M.; Tolomelli, A. Org. Lett. 2001, 3, 1165-1167. (f) Börner, C.; Dennis, M. R.; Sinn, E.; Woodward, S. Eur. J. Org. Chem. 2001, 2435-2446. (g) Nishimura, K.; Tomioka, K. J. Org. Chem. 2002, 67, 431-434. (h) Dambacher, J.; Anness, R.; Pollock, P.; Bergdahl, M. Tetrahedron 2004, 60, 2097-2110. (i) Davies, S. G.; Hermann, G. J.; Sweet, M. J; Smith, A. D. Chem. Commun. 2004, 1128-1129. (j) Beddow, J. E.; Davies, S. G.; Ling, K. B.; Roberts, P. M.; Russell, A. J.; Smith, A. D.; Thomson, J. E. Org. Biomol. Chem. 2007, 5, 2812-2825. (k) Davies, S. G.; Foster, E. M.; McIntosh, C. R.; Roberts, P. M.; Rosser, T. E.; Smith, A. D.; Thomson, J. E. Tetrahedron: Asymmetry 2011, 22, 1035-1050.

(3) (a) Tomioka, K.; Shindo, M.; Koga, K. J. Am. Chem. Soc. 1989, 111, 8266-8268. (b) Tomioka, K.; Shioya, Y.; Nagaoka, Y.; Yamada, K. J. Org. Chem. 2001, 66, 70517054, and references therein.

(4) C-nucleophiles: (a) Asano, Y.; Iida, A.; Tomioka, K. Tetrahedron Lett. 1997, 38, 8973-8976. (b) Asano, Y.; Yamashita, M.; Nagai, K.; Kuriyama, M.; Yamada, K.; Tomioka, K. Tetrahedron Lett. 2001, 42, 8493-8495, and references therein.

(5) N-nucleophiles: (a) Doi, H.; Sakai, T.; Iguchi, M.; Yamada, k.; Tomioka, K. J. Am. Chem. Soc., 2003, 125, 2886-2887. (b) Sakai, T.; Doi, H.; Tomioka, K. Tetrahedron 2006, 62, 8351-8359, and references therein.

(6) S-nucleophiles: (a) Nishimura, K.; Ono, M.; Nagaoka, Y.; Tomioka, K. J. Am. Chem. Soc. 1997, 119, 1297412975. (b) Nishimura, K.; Ono, M.; Nagaoka, Y.; Tomioka, K. Angew. Chem., Int. Ed. 2001, 40, 440-442. See also ref $2 \mathrm{~g}$.

(7) (a) Yamashita, M.; Yamada, K.; Tomioka, K. J. Am. Chem. Soc. 2004, 126, 1954-1955. (b) Valleix, F.; Nagai, K.; Soeta, T.; Kuriyama, M.; Yamada, K.; Tomioka, K. Tetrahedron 2005, 61, 7420-7424, and references therein.

(8) Of course $\mathrm{sp}^{3}$ character of lithium and Li-R bond constitute a destroying factor of perfect $C_{2}$-symmetry.

(9) (a) Yamamoto, Y.; Yasuda, Y.; Oulyadi, H.; Maddaluno, J.; Tomioka, K. Tetrahedron 2010, 66, 2470-2473. (b) Yamamoto, Y.; Nasu, H.; Tomioka, K. Tetrahedron 2013, 69, 3836-3840.

(10) Ester substituent R' of enoate in Scheme 1 affects the stereoselectivity. In the asymmetric conjugate addition of lithium amide $(\mathrm{R}=\mathrm{N}(\mathrm{Bn}) \mathrm{TMS})$, the ee of the reac- 
tion of tert-butyl crotonate was $97 \%$, whereas that of methyl crotonate was $85 \%$ (see ref $5 \mathrm{a}$ ). These results indicated that an enoate with bulky ester substituent preferred the coordination to lithium as shown in $\mathbf{X}$.

(11) Corey, E. J.; Peterson, R. T. Tetrahedron Lett. 1985, 26, 5025-5028.

(12) Uchiyama, M.; Nakamura, S.; Furuyama, T.; Nakamura, E.; Morokuma, K. J. Am. Chem. Soc. 2007, 129, 1336013361.

(13) Diastereoselective conjugate addition cascades of dienedioates: (a) Saito, S.; Hirohara, Y.; Narahara, O.; Moriwake, T. J. Am. Chem. Soc. 1989, 111, 4533-4535. (b) Saito, S.; Hara, T.; Naka, K.; Hayashi, T.; Moriwake, T. Synlett 1992, 241-243. (c) Klimko, P. G.; Singleton, D. A. J. Org. Chem. 1992, 57, 1733-1740. (d) Uyehara, T.; Shida, N.; Yamamoto, Y. J. Org. Chem. 1992, 57, 3139-3145. (e) Shida, N.; Uyehara, T.; Yamamoto, Y. J. Org. Chem. 1992, 57, 5049-5051. (f) Yoshii, E.; Hori, K.; Nomura, K.; Yamaguchi, K. Synlett 1995, 568-571. (g) Urones, J. G.; Garrido, N. M.; Díez, D.; Dominguez, S. H.; Davies, S. G. Tetrahedron: Asymmetry 1997, 8 , 2683-2685. (h) Davies, G.; Díez, D.; Dominguez, S. H.; Garrido, N. M.; Kruchinin, D.; Price, P. D.; Smith, A. D. Org. Biomol. Chem. 2005, 3, 1284-1301.

(14) Our other approaches of conjugate addition-triggered cascade reactions: (a) Nagaoka, Y.; Tomioka, K. Org. Lett. 1999, 1, 1467-1469. (b) Ono, M.; Nishimura, K.; Tsubouchi, H.; Nagaoka, Y.; Tomioka, K. J. Org. Chem. 2001, 66, 8199-8203. (c) Inoue, H.; Nagaoka, Y.; Tomioka, K. J. Org. Chem. 2002, 67, 5864-5867. (d) Yamamoto, Y.; Yasuda, Y.; Nasu, H.; Tomioka, K. Org. Lett. 2009, 11, 2007-2009. (e) Yamada, K.; Konishi, T.; Nakano, M.; Fujii, S.; Cadou, R.; Yamamoto, Y.; Tomioka, K. J. Org. Chem. 2012, 77, 5775-5780. (f) Harada, S.; Sakai, T.; Takasu, K.; Yamada, K.; Yamamoto, Y.; Tomioka, K. J. Org. Chem. 2012, 77, 7212-7222. (g) Harada, S.; Sakai, T.; Takasu, K.; Yamada, K.; Yamamoto, Y.; Tomioka, K. Tetrahedron 2013, 69, 3264-3273, and references therein.

(15) Our preliminary report: (a) Yamada, K.; Yamashita, M.; Sumiyoshi, T.; Nishimura, K.; Tomioka, K. Org. Lett. 2009, 11, 1631-1633. (b) Nishimura, K.; Fukuyama, N.; Yasuhara, T.; Yamashita, M.; Sumiyoshi, T.; Yamamoto, Y.; Yamada, K.; Tomioka, K. Tetrahedron, in press, doi:10.1016/j.tet.2015.03.014

(16) The inverse addition (adding phenyllithium to a solution of $\mathbf{6 b})$ significantly prevented the formation of $10 \mathbf{a}(8 \%)$ and improved the yield of $\boldsymbol{t t}-\mathbf{7 a}$ and $\boldsymbol{t c}-7 \mathbf{a}$ to $52 \%$ and $5 \%$ yields, respectively.

(17) Yasuhara, T.; Nishimura, K.; Yamashita, M.; Fukuyama, N.; Yamada, K.; Muraoka, O.; Tomioka, K. Org. Lett. 2003, 5, 1123-1126.

(18) (a) Ireland, R. E.; Mueller, R. H.; Willard, A. K. J. Am. Chem. Soc. 1976, 98, 2868-2877. (b) Heathcock, C. H.; Buse, C. T.; Kleschick, W. A.; Pirrung, M. C.; Sohn, J. E.; Lampe, J. J. Org. Chem. 1980, 45, 1066-1081.

(19) Shindo, M.; Koga, K.; Tomioka, K. J. Org. Chem. 1998, 63, 9351.

(20) Randl, S.; Connon, S. J.; Blechert, S. Chem. Commun. 2001, 1796-1797. 